\title{
sciendo
}

\section{Determinants of Tax Morale in Croatia: an Ordered Logit Model}

\author{
Predrag Bejaković \\ Institute of Public Finance, Zagreb, Croatia \\ Slavko Bezeredi \\ Institute of Public Finance, Zagreb, Croatia
}

\section{Abstract}

Background: A lower tax morality leads to an increased readiness to become active in the unofficial economy and causes the lack of public revenues. Objectives: The aim of this paper is to investigate determinants that shape tax morale of Croatian citizens. Methods/Approach: An ordered logit model is employed to evaluate which determinants shape tax morale of Croatian citizens. Data for the research were collected from 2,000 face-to-face interviews conducted in Croatia in late 2015. Results: The descriptive analysis illustrates that 52 percent of respondents reported a high level of tax morale, 26 percent of respondents have a low tax morale, while 8 and 14 percent have a mid-low and a mid-high tax morale, respectively. The ordered logit analysis revealed that gender, age, financial situation, region, and participation in the unofficial economy have an impact on the tax morale. Conclusions: Besides socio-demographic, socio-economic, and spatial determinants, a great number of sanctions for participation in informal activities also shapes tax morale of the Croatian citizens. More precisely, marginal effects show that those perceiving the expected sanctions as "normal tax or social security contributions due, plus a fine or a prison sentence" have by 6.3 percentage points higher probability of reporting the highest tax morale than others.

Keywords: Croatia, ordered logit model, tax evasion, tax morale

JEL classification: C25, H26, K42, O17

Paper type: Research article

Received: Jun 04, 2018

Accepted: Jan 03, 2019

Citation: Bejaković, P., Bezeredi, S. (2019), "Determinants of Tax Morale in Croatia: an Ordered Logit Model", Business Systems Research, Vol. 10, No. 2, pp. 37-48.

DOI: 10.2478/bsri-2019-016

\section{Introduction}

Luttmer et al. (2014) in their seminal work define tax morale "as an umbrella term capturing nonpecuniary motivations for tax compliance as well as factors that fall outside the standard, expected utility framework". They argue that Allingham et al. (1972) have constructed the benchmark economic model of tax evasion, in which the most important parameters having an effect on tax evasion are the tax rate, the detection risk, and the punishment for the detected individuals who evade paying taxes. In the mentioned model, a rational taxpayer evades to pay taxes as long as the 
cost of being caught and punished is smaller than the benefit from tax evasion. Since this contribution, there has been an increased interest in analysing and enhancing the knowledge on "tax morale". Modern fiscal literature by it means improving voluntary compliance with tax regulation and achieving a social norm of compliance (Wenzel, 2005a; 2005b).

Luttmer et al. (2014) state that taxpayers may have some intrinsic motivation, which is a key instrument that helps them to respect the law and pay taxes or feel some moral guilt for failure to comply. They may respect the law due to the groups of various reasons. The first group is reciprocal motivations, i.e. the readiness to pay taxes in exchange for goods and services that the state provides to all citizens even though their monetary benefits would be bigger if they did not pay taxes (Luttmer et al., 2014). The second group may be various forms of the pressure from peer behaviour and the prospect of social recognition or sanctions from friends, neighbours, family members or co-workers. The third group consists of cultural or social norms like traditions, prevailing values and believes that can affect compliance and morale, but are also under the influence of various forms of motivation and the peers' sensitivity. The fourth group includes the level of tax knowledge or tax literacy that influences compliance attitudes and decisions of current and potential taxpayers (Nichita, 2015). The fifth group contains deviations from utility maximization and information imperfections (for example, taxpayers may over- or underestimate the probability of being caught in tax evasion or may show loss aversion). Finally, the last group contains a policy and administration aspect: the behaviour and practice of the tax administration and the perceived tax burden, the tax structure in general as well as the tax enforcement strategy can influence taxpayers' decision to pay taxes (Torgler et al., 2005).

There are two main types of tax behaviour: compliance, which is either voluntary or enforced; and noncompliance that can be in the form of tax evasion or tax avoidance (OECD/FIIAPP, 2015). Many authors (Lago-Peñas et al., 2010; Kogler et al., 2013; Luttmer et al., 2014) believe that tax morale plays an important role in the tax compliance, although very often they see enforcement as the main reason of compliance. The main determinants of the tax morale expressing dissent against formal institutions are often connected with the existing or perceived infringement of the principle of equality by the same public authority (Chong et al., 2007). In particular, the tax policy and social security system are defined by regulations, which a part of the population judges as unfair according to the principle of equality and to its corollary, the ability-to-pay principle. As an outcome, people who withdraw from their fiscal obligations and accept a negative tax morale are able to justify their noncompliance with the rule. Such a negative tax morale is not only a causal element of the informal economy; it is very often also a cause of exclusion from a legal system expecting duties, but also from various rights.

These considerations suggest that designing tax measures in accordance with the principle of equality is fundamental for increasing their effectiveness and for promoting a shift from the negative to the positive tax morale. The shift from the negative to the positive tax morale is the transformation of noncompliance into compliance, which is an essential condition for promoting the stable inclusion into the formal world of work and compliance regarding tax and social security obligations.

The aim of this paper is to evaluate the determinants that shape tax morale of Croatian citizens. To do this, an ordered logit model is conducted based on data collected in Croatia in 2015. Croatia is a post-transition society, which emerged from a socialist system, and experienced damages of the Homeland war in the 1990s. It is important to underline that the practices and principles of tax systems under socialism have significantly influenced the path of tax reform during the transition period (Nerré 
et al., 2014). Furthermore, Schneider (2017) estimates that Croatia is a country with one of the highest level of the undeclared economy among all EU-28 member states in 2015 (27.7\% of GDP), only Bulgaria (30.6\% of GDP) and Romania ( $28.0 \%$ of GDP) have higher levels of the undeclared economy, while the EU-28 average is $18.3 \%$ of GDP. Accordingly, the mentioned facts are the main motivation and reason for choosing Croatia as a country for research.

This paper is the first that examines the impact of expected size of sanction for participation in informal activities and various socio-demographic, socio-economic, and spatial factors on tax morale in Croatia. The literature about informal economy reveals that higher tax morale leads to a smaller shadow economy (Torgler et al., 2007; Torgler et al., 2009) and the lower levels of participation in the informal economy (Williams et al., 2015; Williams et al., 2016a; Windebank et al., 2017; Franić et al., 2017). Thus, this article contributes to a better understanding of the determinants of tax morale as well as informal economy in Croatia. The paper provides an overview of the literature in Section 2 and a summary of the empirical evidence of the socioeconomic and institutional determinants of tax morale in the following sections.

\section{Literature review}

Nerré (2008) deems that a tax culture is a specific characteristic of a particular country. It was coined by the tradition of taxation (having in mind various forms of taxes) on the one side, and by the interaction of the stakeholders and the cultural values like honesty, justice or also a sense of duty on the other side. Lago-Peñas et al. (2010) divide the literature on the tax culture into two categories. First group consists of those studies oriented only on one country, but after then authors usually compare international or regional variations and changes over time. Examples of such approach are researches Torgler (2005a), Martínez-Vázquez et al. (2009), Nerré et al. (2014), and Williams et al. (2014). Torgler (2005a) examine the impact of direct democracy on tax morale in Switzerland, and concluded that "direct democratic rights have a significantly positive effect on tax morale". Martínez-Vázquez et al. (2009) argue that an increased level of the tax morale in Spain was an endogenous variable influenced primarily by improved tax policy and tax administration reforms. Nerré et al. (2014), as several more important reasons for low tax morale in Serbia, mention high tax rates, unjust distribution of tax burden and lack of detection, while other less important reasons were corruption among civil servants and a lack of civic conscience. Williams et al. (2014) conducted a resesarch for Bulgaria in 2013 and have propounded an explanation for the undeclared economy, which claims the following "the greater is the asymmetry between formal and informal institutions (i.e., citizens' civic morality and state morality), the greater is the likelihood of participation in the undeclared economy, and vice versa".

Similar to one measurement approach on the tax morale, there is a possibility to evaluate the magnitude of tax morale via surveys. Torgler et al. (2005) state that "The World Values Survey provides a valuable data source for getting internationally comparable information on tax morale". They explain that the mentioned Survey uses the following question: "Please tell us for each of the following statements whether you think it can always be justified, never be justified, or something in between: ... Cheating on tax if you have the chance". The question leads to a ten-scale index of tax morale with the two extreme points "never justified" and "always justified". The ten-point scale has been integrated into a four-point scale (from 0 to 3), with the value 3 for "never justifiable". According to results from various years, the highest share of the people that state how tax evasion is never justified has been recorded in Japan (more than $80 \%$ ), followed by USA (around 70\%) and Switzerland (around 60\%). This 
value decreases to around $40 \%$ in Portugal, the Netherlands and Finland and is even lower in Belgium (below 35\%).

Another approach to measuring tax morale is by using the International Social Survey Programme (ISSP). This cross-national collaboration began in 1983 and has grown to more than 30, mostly European, countries (Croatia has been a member since 2005) and enables various types of social science projects. From time to time, the Programme asks the following question: "Do you feel it is wrong or not wrong if a taxpayer does not report all of his or her income in order to pay less personal income taxes? (1= not wrong, 2= a bit wrong, 3= wrong, 4=seriously wrong)". ISSP Mean Tax Morale Values are low for Austria, Germany, Ireland and France and high for Australia, Sweden, Spain and Japan. Unfortunately, there is little overlapping of the results from various surveys and it is almost impossible to compare the variables from different sources (Schneider, 2011).

Unlike the researchers oriented only on one country, the second group includes researches that make use of cross-national data. Using data from six countries, Torgler (2004) concludes that tax morale increases with age and is lower for self-employed, unemployed, and upper class taxpayers. Financial satisfaction, strong GDP growth, institutional quality, national pride, trust in government and legal system increase tax morale and decrease tax evasion. Similar results were obtained by other researches that added to the existing knowledge or provide possible explanations. Thus, Tittle (1980) deems that significantly higher tax morale recorded by women is caused by the facts that females are more compliant than males, and thus, are more risk averse. Furthermore, the modern female generations are much more independent than the former generations, and it is assumed that they will comply less (Torgler et al., 2005). As for elderly people, Tittle (1980) argues that they are more sensitive to the threats of sanctions than others. Furthermore, Torgler et al. (2005) argue that older people attained their social stakes over the years, as property or social status, and that they are more sensitive to the reactions from others. Consequently, they also state that their potential costs of sanction due to tax evasion increase. Chong et al. (2007) argue that high or increased income inequality, in combination with unsatisfactory quality of institutions, is one of the most important determinants of low tax morale. After the analysis of the tax culture of the 50 countries surveyed, Tsakumis et al. (2007) state that cultural framework based on male-oriented individualism, causes lower readiness to pay taxes. Finally, Lago-Peñas et al. (2010) claim that well educated taxpayers are supposed to know more about the fiscal legislations and tax because they are more aware of the importance of public goods provided by the state.

\section{Methodology}

To evaluate which socio-economic, socio-demographic, and spatial determinants shape tax morale of the Croatian citizens, data were collected from 2,000 face-toface interviews conducted in Croatia between August 20th and October 9th 2015. The survey was conducted by well-known Croatian market research agency "Ipsos Puls". To get a nationally representative sample of the population, the sample was drawn according to official data gather in Census 2011 by the Croatian Bureau of Statistics and a two-way stratified random sample was used according to regions and settlement size. In each surveyed household, one respondent aged 18 years and older was selected using the "first birthday" method. To collect the data, trained professional interviewers used face-to-face methodology (TAPI - Tablet Assisted Personal Interview). Furthermore, to balance under- and over-representation in the sample, weighting procedure based on age, gender, education, region and settlement size was applied. The main advantage of the cross-sectional surveys is that 
these surveys target different members of the population and together with the appropriate sampling method, these are the main factors that make the survey as representative as possible. On the other hand, a weakness of cross-sectional sample surveys is their inability to track change over time.

\section{Table 1}

The list of variables used in the analysis

\begin{tabular}{|c|c|c|c|}
\hline Variables & Definition & Values & $\begin{array}{l}\text { \# of } \\
\text { missing } \\
\text { values }\end{array}$ \\
\hline \multicolumn{4}{|c|}{ Dependent variable: } \\
\hline Tax morale & $\begin{array}{l}\text { A categorical variable which estimates the level } \\
\text { of tax morale using the following survey question: } \\
\text { "Now I would like to know how you assess various } \\
\text { behaviours. For each of them, please tell me to } \\
\text { what extent you find it acceptable or not. Please } \\
\text { use the following 10-point Likert scale: '1' means } \\
\text { that you find it 'absolutely unacceptable' and } \\
\text { '10' means that you find it 'absolutely } \\
\text { acceptable'.... Someone evades taxes by not or } \\
\text { only partially declaring income." }\end{array}$ & $\begin{array}{l}\text { The } 10 \text {-point scale has been } \\
\text { recoded into a four-point scale: } \\
1=\text { low tax morale (responses } \\
\text { from } 4 \text { through 10); } \\
\text { value } 2=\text { mid low tax morale } \\
\text { (response 3); } \\
\text { value } 3=\text { mid high tax morale } \\
\text { (response 2); value } 4=\text { high tax } \\
\text { morale (response } 1 \text { "completely } \\
\text { disagree"). }\end{array}$ & 38 \\
\hline \multicolumn{4}{|c|}{ Explanatory variables: } \\
\hline Gender & $\begin{array}{l}\text { A dummy variable indicating the respondent's } \\
\text { gender. }\end{array}$ & $\begin{array}{l}0=\text { men } \\
1=\text { women. }\end{array}$ & 0 \\
\hline Age & $\begin{array}{l}\text { An interval variable indicating the exact age of } \\
\text { the respondent. }\end{array}$ & $\begin{array}{l}\text { Exact age of the respondent ( } 18 \\
\text { or more) }\end{array}$ & 0 \\
\hline $\begin{array}{l}\text { Employment } \\
\text { status }\end{array}$ & $\begin{array}{l}\text { A categorical variable for the employment } \\
\text { status of the respondents. }\end{array}$ & $\begin{array}{l}1=\text { employed; } \\
2=\text { self-employed; } \\
3 \text { = unemployed; } \\
4 \text { = retired; } \\
5 \text { = student and inactive. }\end{array}$ & 0 \\
\hline $\begin{array}{l}\text { Financial } \\
\text { situation }\end{array}$ & $\begin{array}{l}\text { A categorical variable for the respondent } \\
\text { perception regarding its financial situation. }\end{array}$ & $\begin{array}{l}1 \text { = struggling; } \\
2 \text { = maintaining; } \\
3 \text { = just comfortable or no } \\
\text { money problems. }\end{array}$ & 45 \\
\hline Household size & $\begin{array}{l}\text { A categorical variable which measures the size } \\
\text { of the respondent's household. }\end{array}$ & $\begin{array}{l}1=\text { one person; } \\
2=\text { two persons; } \\
3=\text { three persons; } \\
4=\text { four or more people. }\end{array}$ & 0 \\
\hline Region & $\begin{array}{l}\text { A categorical variable for the region to which } \\
\text { the respondent belongs. }\end{array}$ & $\begin{array}{l}1 \text { = Zagreb and surroundings; } \\
2 \text { = North Croatia; } \\
3 \text { = Slavonia; } \\
4 \text { = Lika and Banovina; } \\
5 \text { = Gorki Kotar, Hrvatsko } \\
\text { Primorje and Istria; } \\
6 \text { = Dalmatia. }\end{array}$ & 0 \\
\hline $\begin{array}{l}\text { Participation in } \\
\text { undeclared work }\end{array}$ & $\begin{array}{l}\text { A dummy variable which indicates participation } \\
\text { in undeclared work using the following survey } \\
\text { question: } \\
\text { "Did you yourself carry out any undeclared paid } \\
\text { activities in the last } 12 \text { months?" }\end{array}$ & $\begin{array}{l}0=\text { no } \\
1=\text { yes }\end{array}$ & 41 \\
\hline $\begin{array}{l}\text { Purchasing } \\
\text { goods and } \\
\text { services on the } \\
\text { informal market }\end{array}$ & $\begin{array}{l}\text { A dummy variable which indicates purchasing } \\
\text { goods and services on the informal market using } \\
\text { the following survey question: } \\
\text { "Have you in the last } 12 \text { months paid for any } \\
\text { goods or services of which you had a good } \\
\text { reason to assume that they included undeclared } \\
\text { work (e.g. because there was no invoice or VAT } \\
\text { receipt)?" }\end{array}$ & $\begin{array}{l}0=\text { no } \\
1=\text { yes }\end{array}$ & 72 \\
\hline $\begin{array}{l}\text { Expected } \\
\text { sanctions }\end{array}$ & $\begin{array}{l}\text { A categorical variable describing the expected } \\
\text { size of sanctions when someone is engaged in } \\
\text { unregistered activities. }\end{array}$ & $\begin{array}{l}1 \text { = normal tax or social security } \\
\text { contributions due, but no fine; } \\
2=\text { normal tax or social security } \\
\text { contributions due, plus a fine or } \\
\text { a prison. }\end{array}$ & 344 \\
\hline
\end{tabular}

Source: Authors' work 
In this paper the dependent variable is tax morale that measures individuals' attitude about the moral obligation to pay taxes. To estimate the level of tax morale from the survey, the following question is used: "Now I would like to know how you assess various behaviours. For each of them, please tell me to what extent you find it acceptable or not. Please use the following 10-point Likert scale: "1' means that you find it 'absolutely unacceptable' and '10' means that you find it 'absolutely acceptable'.... Someone evades taxes by not or only partially declaring income." As in Torgler (2004), and Torgler et al. (2009), the 10-point scale has been redefined into a four point scale $(1,2,3,4)$, with the value 4 for "absolutely unacceptable". Responses 4 through 10 were integrated into a value 1 due to lack of variance among them. The explanatory variables used to analyse the determinants of tax morale were selected based on previous studies of the informal economy and tax morale (Torgler 2004; Williams et al., 2017; Williams et al., 2018). The list of used variables is shown in Table 1. Given that the data contain missing values (i.e. 'don't know' and refusal), multiple imputation procedure was applied to predict the values (Rubin, 1987, Royston, 2004; Schafer et al., 2002). More precisely, using a system of chained equations, twenty five imputations were simulated for each missing value.

Given that the dependent variable is an ordered categorical variable, an ordered logit model is here applied and then the average marginal effects are calculated. The ordered logit model is defined as (Cameron et al., 2005):

$$
\begin{aligned}
& y_{i}^{*}=\beta x_{i}+\varepsilon_{i} \\
& y_{i}=j \text { if } \delta_{j-1}<y_{i}^{*} \leq \delta_{j},
\end{aligned}
$$

where $j=1, \ldots, M$ and $i=1, \ldots, N . M$ denotes the total number of alternatives of the dependent variable and $N$ denotes the sample size. Furthermore, $x_{i}$ is a column vector of explanatory variables, $\beta$ is a row vector of parameters to be estimated and $\varepsilon_{i}$ is the logistic distributed random error. The unknown parameters $\delta_{j}$ 's represent threshold parameters to be estimated along with $\beta$, where $\delta_{0}=-\infty$ and $\delta_{M}=+\infty$ (Cameron et al., 2005). Finally, the probability that observation $i$ will choose alternative $j$ is:

$$
P\left[y_{i}=j\right]=P\left[\delta_{j-1}<y_{i}^{*} \leq \delta_{j}\right]=F\left(\delta_{j}-\beta x_{i}\right)-F\left(\delta_{j-1}-\beta x_{i}\right),
$$

where $F$ is the standard logistic cumulative distribution function

$$
F(\phi)=\frac{e^{\phi}}{1+e^{\phi}} .
$$

Finally, the marginal effect of an increase in an independent variable for the $j$-th response is given by (Mallick, 2009)

$$
\frac{\partial P[y=j \mid x]}{\partial x_{k}}=\beta_{k}\left[F^{\prime}\left(\delta_{j-1}-\beta x_{i}\right)-F^{\prime}\left(\delta_{j}-\beta x_{i}\right)\right] .
$$

\section{Findings}

This study of a nationally representative sample in Croatia reveals that 52.1 percent of respondents reported that tax evasion is never justifiable (high level of tax morale), 26.0 percent of respondents have low tax morale, while 8.4 and 13.5 percent have mid low and mid high tax morale, in turn. To examine which population groups more frequently state the high level of tax morale, Table 2 illustrates the descriptive results. 
The descriptive statistics reveals that women more frequently report high level of tax morale than man (54.6 percent compared with 49.4 percent) and that the proportion of declaring high level of tax morale increases as age increases. Having a high level of tax morale is less common among those struggling financially, those participating in the undeclared work and among those purchasing on informal markets. Reporting high level of tax morale also appears to be more prevalent in some regions (i.e. Zagreb and surroundings, Lika and Banovina) than the rest of the country. Those who perceive the size of sanctions when someone is engaged in informal activities to be higher more frequently reported high level of tax morale.

Table 2

Distribution of tax morale in Croatia, \% of survey respondents

\begin{tabular}{|c|c|c|c|c|}
\hline & \multicolumn{4}{|c|}{ Tax morale } \\
\hline & Low & Mid low & Mid high & High \\
\hline Total & 26.0 & 8.4 & 13.5 & 52.1 \\
\hline \multicolumn{5}{|l|}{ Gender } \\
\hline Male & 28.7 & 9.0 & 12.9 & 49.4 \\
\hline Female & 23.6 & 7.8 & 14.0 & 54.6 \\
\hline \multicolumn{5}{|l|}{ Age } \\
\hline $15-24$ & 31.3 & 11.4 & 17.6 & 39.7 \\
\hline $25-39$ & 29.6 & 9.3 & 15.7 & 45.4 \\
\hline $40-54$ & 26.9 & 9.6 & 13.0 & 50.5 \\
\hline $55-64$ & 23.0 & 5.6 & 12.0 & 59.4 \\
\hline $65+$ & 19.4 & 6.0 & 9.4 & 65.2 \\
\hline \multicolumn{5}{|l|}{ Employment status } \\
\hline Employed & 26.6 & 9.4 & 13.7 & 50.3 \\
\hline Self-employed & 32.6 & 15.5 & 14.1 & 37.8 \\
\hline Unemployed & 31.6 & 8.0 & 14.3 & 46.1 \\
\hline Retired & 20.4 & 5.2 & 11.0 & 63.4 \\
\hline Student and inactive & 29.6 & 11.5 & 17.8 & 41.1 \\
\hline \multicolumn{5}{|l|}{ Financial situation } \\
\hline Struggling & 29.6 & 6.4 & 14.9 & 49.1 \\
\hline Maintaining & 22.6 & 8.9 & 12.6 & 55.9 \\
\hline Just comfortable/ No money problems & 26.1 & 10.6 & 12.7 & 50.6 \\
\hline \multicolumn{5}{|l|}{ Household size } \\
\hline One person & 22.8 & 4.6 & 15.9 & 56.7 \\
\hline Two persons & 27.1 & 8.8 & 12.2 & 51.9 \\
\hline Three persons & 26.7 & 9.7 & 16.6 & 47.0 \\
\hline Four or more people & 26.8 & 9.4 & 11.1 & 52.7 \\
\hline \multicolumn{5}{|l|}{ Region } \\
\hline Zagreb and surroundings & 22.5 & 5.2 & 13.9 & 58.4 \\
\hline North Croatia & 24.4 & 9.3 & 12.3 & 54.0 \\
\hline Slavonia & 27.5 & 9.7 & 14.8 & 48.0 \\
\hline Lika and Banovina & 16.4 & 11.5 & 14.8 & 57.3 \\
\hline Gorski Kotar, Hrvatsko Primorje and Istria & 36.3 & 8.7 & 21.8 & 33.2 \\
\hline Dalmatia & 28.8 & 9.1 & 6.7 & 55.4 \\
\hline \multicolumn{5}{|l|}{ Participation in undeclared work } \\
\hline No & 23.3 & 8.1 & 14.0 & 54.6 \\
\hline Yes & 46.9 & 10.3 & 9.9 & 32.9 \\
\hline \multicolumn{5}{|l|}{$\begin{array}{l}\text { Purchasing goods and services on the informal } \\
\text { market }\end{array}$} \\
\hline No & 21.5 & 7.4 & 13.8 & 57.3 \\
\hline Yes & 38.4 & 10.9 & 12.3 & 38.4 \\
\hline \multicolumn{5}{|l|}{ Expected sanctions } \\
\hline $\begin{array}{l}\text { Normal tax or social security contributions } \\
\text { due, but no fine }\end{array}$ & 27.6 & 8.4 & 12.7 & 51.3 \\
\hline $\begin{array}{l}\text { Normal tax or social security contributions } \\
\text { due, plus a fine/ prison }\end{array}$ & 20.8 & 8.4 & 14.6 & 56.2 \\
\hline
\end{tabular}

Source: Authors' work based on the representative survey of 2,000 individuals in Croatia 
To determine which types of Croatian citizens display a greater statistically significant association to have a high level of tax morale, Table 3 illustrates the results of an ordered logit regression analysis. As a robustness check of the results, an ordered probit model and linear regression model were estimated to see if the results are robust considering the change of the empirical methodology. The significance and the signs of the coefficients are the same in all three models. Furthermore, ordered logit and ordered probit models provide almost the same size of the marginal effect. Therefore, it can be concluded that the results are robust. The results show that the propensity to have a high level of tax morale is greater among women, older age groups, and those who are not struggling financially. Many researchers show that tax morale rises with age. On the other hand, some of them illustrate that tax morale is stronger in the case of women (Torgler, 2006; Lago-Peñas et al., 2010; Hug et al., 2011; Torgler, 2012; Williams et al., 2016b), while Torgler (2005b) and Daude et al. (2010) show the opposite for the countries of the Latin America. Many researchers also state that financial situation increases tax morale (Torgler, 2005b; 2006; Lago-Peñas et al., 2010; Ristovska et al., 2013), while Daude et al. (2010) get negative correlation between satisfaction with financial situation and the high level of tax morale.

Table 3

Ordered logit regression analysis of the tax morale determinants in Croatia

\begin{tabular}{|c|c|c|}
\hline & Coefficient (Standard error) & $\begin{array}{c}\text { Marginal } \\
\text { effect }\end{array}$ \\
\hline Female & $0.161(0.095)^{*}$ & 0.037 \\
\hline Age & $0.017(0.004)^{* * *}$ & 0.004 \\
\hline \multicolumn{3}{|l|}{ Employment status (RC: Unemployed) } \\
\hline Employed & $0.097(0.144)$ & 0.022 \\
\hline Self-employed & $-0.259(0.245)$ & -0.059 \\
\hline Retired & $0.160(0.184)$ & 0.037 \\
\hline Student and inactive & $-0.081(0.185)$ & -0.019 \\
\hline \multicolumn{3}{|l|}{ Financial situation (RC: Struggling) } \\
\hline Maintaining & $0.336(0.111)^{* * *}$ & 0.077 \\
\hline Just comfortable/ No money problems & $0.206(0.128)^{*}$ & 0.047 \\
\hline \multicolumn{3}{|l|}{ Household size (RC: One person) } \\
\hline Two persons & $-0.138(0.136)$ & -0.031 \\
\hline Three persons & $0.056(0.147)$ & 0.013 \\
\hline Four or more people & $0.218(0.145)$ & 0.049 \\
\hline \multicolumn{3}{|l|}{ Region (RC: Zagreb and surroundings) } \\
\hline North Croatia & $-0.189(0.148)$ & -0.043 \\
\hline Slavonia & $-0.329(0.143)^{* *}$ & -0.076 \\
\hline Lika and Banovina & $0.003(0.176)$ & 0.001 \\
\hline Gorski Kotar, Hrvatsko Primorje and Istria & $-0.856(0.150)^{* * *}$ & -0.196 \\
\hline Dalmatia & $-0.185(0.144)$ & -0.042 \\
\hline Participation in undeclared work & $-0.578(0.174)^{* * *}$ & -0.132 \\
\hline $\begin{array}{l}\text { Purchasing goods and services on the informal } \\
\text { market }\end{array}$ & $-0.622(0.110)^{* * *}$ & -0.142 \\
\hline \multicolumn{3}{|l|}{$\begin{array}{l}\text { Expected sanctions (RC: Normal tax or social } \\
\text { security contributions due, but no fine) }\end{array}$} \\
\hline $\begin{array}{l}\text { Normal tax or social security contributions due, } \\
\text { plus a fine / prison }\end{array}$ & $0.278(0.105)^{* * *}$ & 0.063 \\
\hline Number of observations & 2,000 & \\
\hline Number of imputations & 25 & \\
\hline Prob > F & 0.000 & \\
\hline
\end{tabular}

Source: Authors' work based on the representative survey of 2,000 individuals in Croatia Notes: (1) We report the marginal effects for the highest score of the tax morale index (4) (2) Significance: ${ }^{*} p<0.05,{ }^{* *} p<0.01,{ }^{* * *} p<0.001$ 
The findings also illustrate that there are statistically significant correlations between the regions and the level of tax morale. More precisely, according to our research those living in Slavonia or in Gorski Kotar, Hrvatsko Primorje and Istria have a lower level of tax morale than others. As Williams et al. (2016b) show for the European Union, the results indicate that participants in the undeclared work and purchasers of goods and services on the informal market have a significantly lower level of tax morale than others. Indeed, participation in undeclared work decreases the probability of reporting the highest tax morale by 13.2 percentage points, while purchasing goods and services on the informal market decreases it by 14.2 percentage points (please see Table 3 and Figure 1). The additional finding is that the expected size of sanctions when someone is engaged in informal activities have also an impact on the tax morale. Furthermore, marginal effects show that those perceiving the expected sanctions for participation in informal activities as "normal tax or social security contributions due, plus a fine or prison" have by 6.3 percentage point higher probability of reporting the highest tax morale than others.

Figure 1

Marginal effects on probability of high level of tax morale, \%

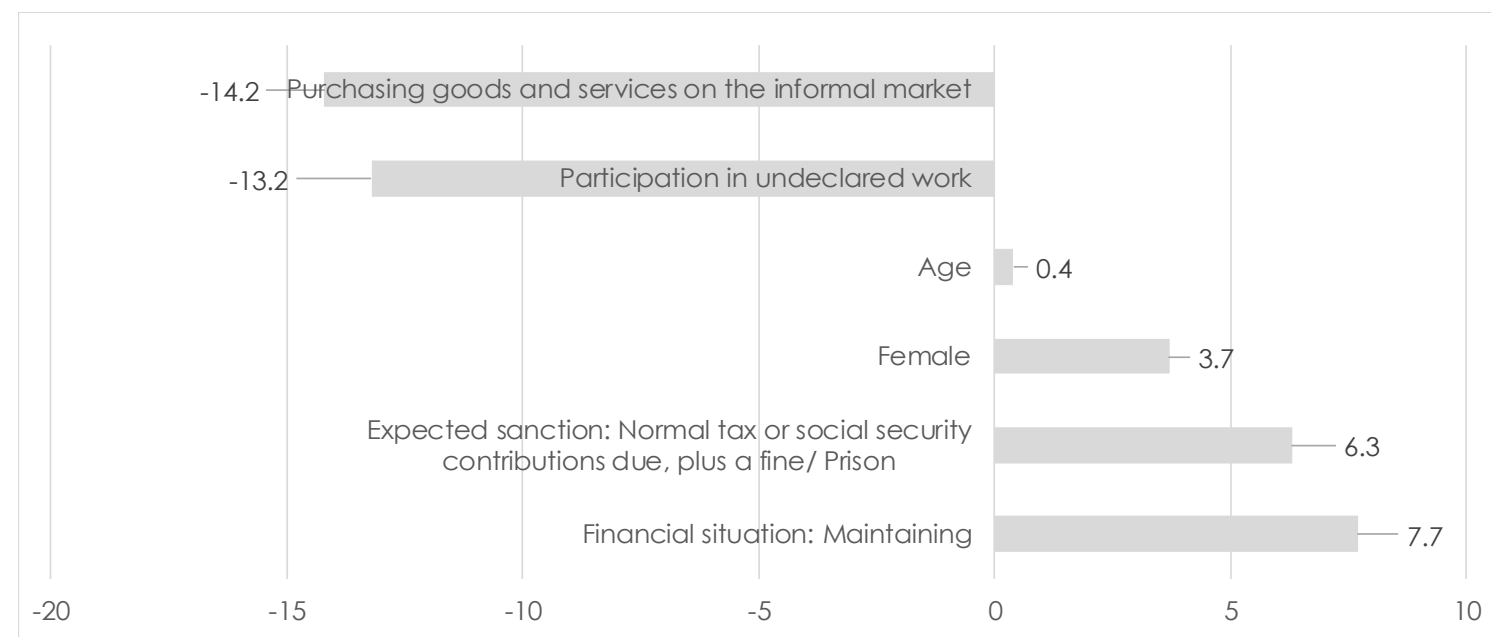

Source: Authors' work based on the representative survey of 2,000 individuals in Croatia Notes: For categorical variable: Financial situation the marginal effect reflects the difference between the financial situation "Maintaining" and "Struggling".

\section{Discussion and conclusion}

Torgler et al. (2009) define tax morale "as the intrinsic motivation to pay taxes. It measures an individual's willingness to pay taxes, in other words, the moral obligation to pay taxes or the belief that paying taxes contributes to society". Using ordered logit model, this research analyses the determinants of the tax morale in Croatia. The results of the research are in line with those obtained by various previously realised surveys in other countries - that tax morale is greater among women and older age groups (Torgler, 2005b; Torgler, 2006; Lago-Peñas et al., 2010). Being in a better financial situation and perceiving the high level of sanction for participation in informal activities also increases the probability of reporting the highest level of tax morale. Tax morale itself has many aspects, which are under the influence of a variety of factors. The measures for enhancement of the tax moral are in the field of the tax legislation and tax policy, but also out of it. The tax system should be simple, stable, and predictable, have low tax rates and a broader tax base, almost without exemptions and reductions; while tax laws should be clear and fully respecting its citizens' rights. 
Unnecessary complicated labour law and constant changes in the tax structure and regulations are often used as a justification by those who considered playing against the rules of the game or are operating in the unofficial economy as morally acceptable. Such behaviour is also stimulated by the fact that the law-makers and responsible authorities (sometimes) fail to provide or implement penalties for undesirable forms of the tax conduct. However, the most important factor for achieving an improved tax morale is a strong and sustained economic growth; because in a prosperous and developed economy, most citizens are ready to bear their tax obligation if they feel that tax system is just and/or that the tax burden is distributed fairly among the population. A well-designed and administered tax system enables adequate incentives for investment and growth, and helps - together with targeted social spending policies - to improve income distribution and the fairness of the tax system. A lower tax morality and a feeling of unfairness of the state regarding the use of collected taxes leads to greater willingness of individuals and business units to participate in the hidden economy and increase the tax evasion. The way to raise tax morale is by rational behaviour in the spending of the state budget. Taxpayers who notice that taxes are wisely and efficiently spent on quality public services have greater incentives to comply with tax laws. However, if the state spends public revenues in a reckless mode, does not respect the rule of law, provides inadequate public services, citizens will likely be evading the payment of taxes. Stubborn taxpayers that still attempt to evade payment of taxes would have to be convinced that compliance with tax laws and the payment of taxes brings a greater benefit to society than avoiding the paying taxes.

\section{References}

1. Allingham, M. G., Sandmo, A. (1972), "Income Tax Evasion: A Theoretical Analysis", Journal of Public Economics, Vol. 1, No. 3-4, pp. 323-338.

2. Cameron, A. C., Trivedi, P. K. (2005), Microeconometrics: Methods and Applications, Cambridge University Press, Cambridge.

3. Chong, A., Gradstein, M. (2007), "Inequality and informality", Journal of Public Economics, Vol. 91, No. 1-2, pp. 159-179.

4. Daude, C., Melguizo, A. (2010), "Taxation and More representation? On Fiscal Policy, Social Mo-bility and Democracy in latin America", OECD Development Centre Working Paper 294, OECD, Paris.

5. Franić, J., Williams, C. C. (2017), "Illegitimate Economic Practices in Croatia", GREY Working Paper No. 9, Sheffield University Management School, University of Sheffield, Institute of Public Finance, Zagreb, 2017.

6. Hug, S., Sporri, F. (2011), "Referendums, trust, and tax evasion", European Journal of Political Economy, Vol. 27, No. 1, pp. 120-131.

7. Kogler, C., Batrancea, L., Nichita, A., Pantya, J., Belianin, A., Kirchler, E. (2013), "Trust and power as determinants of tax compliance: Testing the assumptions of the slippery slope framework in Austria, Hungary, Romania and Russia", Journal of Economic Psychology, Vol. 34, pp. 169-180.

8. Lago-Peñas, I., Lago-Peñas, S. (2010), "The determinants of tax morale in comparative perspective: Evidence from European countries", European Journal of Political Economy, Vol. 26, No. 4, pp. 441-453.

9. Luttmer, E. F. P., Singhal, M. (2014), "Tax Morale", Journal of Economic Perspectives, Vol. 28, No. 4, pp. 149-168.

10. Mallick, D. (2009), "Marginal and Interaction Effects in Ordered Response Models", MPRA Paper No. 1332, Munich Personal RePEc Archive, January 2009.

11. Martínez-Vázquez, J., Torgler, B. (2009), "The evolution of tax morale in modern Spain", Journal of Economic, Vol. 43, No. 1, pp. 1-28. 
12. Nerré, B. (2008), "Tax Culture: A Basic Concept for Tax Politics", Economic Analysis and Policy, Vol. 38, No. 1, pp. 153-167.

13. Nerré, B., Dragojlović, A., Randjelović, S., Djenić, M. (2014), "Tax Reform in Serbia: experiences and perspectives", in proceedings of the Tax Reforms: Experiences and Perspectives Conference, Institute of Public Finance, Zagreb, pp. 79-96.

14. Nichita, R. (2015), "Is tax literacy impacting on tax behavior?", Collaboration in complex system, Bucharest: Romanian Foundation for Business Intelligence Seaopenresearch, available on http://seaopenresearch.eu/Proceedings/Article/NORD2 5.pdf (07 December 2018)

15. OECD/FIIAPP (2015), Building Tax Culture, Compliance and Citizenship: A Global Source Book on Taxpayer Education, OECD Publishing, Paris.

16. Ristovska, M., Mojsoska-Blaževski, N., Nikolov, M. (2013), "An alternative view to the tax evasion: The effect of tax morale on paying taxes in Macedonia and EU countries", Serbian Journal of Management, Vol. 8, No.2, pp. 169-183.

17. Royston, P. (2004), "Multiple imputation of missing values", The Stata Journal, Vol. 4, No. 3, pp. 227-241.

18. Rubin, D. B. (1987), Multiple Imputation for Nonresponse in Surveys, John Wiley \& Sons, Inc., New York.

19. Schafer, J. L., Graham, J. (2002), "Missing data: our view of the state of the art", Psychological Methods, Vol. 7, No. 2, pp. 147-177.

20. Schneider, F. (2011), Handbook on the Shadow Economy, Edward Elgar Publishing, Cheltenham.

21. Schneider, F. (2017), "Estimating the Size of the Shadow Economies of Highly-developed Countries: Selected New Results", CESifo DICE Report, ifo Institute - Leibniz Institute for Economic Research at the University of Munich, Vol. 14, No. 4, pp. 44-53.

22. Tittle, C. (1980), Sanctions and social deviance: The question of deterrence, NY: Praeger, New York.

23. Torgler, B. (2004), "Tax morale in Asian countries", Journal of Asian Economics, Vol. 15, No. 2, pp. 237-266.

24. Torgler, B. (2005a), "Tax morale and direct democracy", European Journal of Political Economy, Vol. 21, No. 2, pp. 525-531.

25. Torgler, B. (2005b), "Tax morale in Latin America", Public Choice, Vol. 122, No. 1-2, pp. 133157.

26. Torgler, B., Schaltegger, C. A. (2005), "Tax Morale and Fiscal Policy", Working Paper No. 2005- 30, Center for Research in Economics, Management and the Arts.

27. Torgler, B. (2006), "The importance of faith: tax morale and religiousity", Journal of Economic Behavior \& Organization, Vol. 61, No. 1, pp. 81-109.

28. Torgler, B., Schneider, F. (2007), "What shapes attitudes toward paying taxes? Evidence from multicultural European countries", Social Science Quarterly, Vol. 88, No. 2, pp. 443470.

29. Torgler, B., Schneider, F. (2009), "The impact of tax morale and institutional quality on the shadow economy", Journal of Economic Psychology, Vol. 30, No. 2, pp. 228-245.

30. Torgler, B. (2012), "Tax Morale, Eastern Europe and European Enlargement", Communist and Post-Communist Studies, Vol. 45, No. 1-2, pp. 11-25.

31. Tsakumis, G. T., Curatola A. P., Porcano T. M. (2007), "The relation between national cultural dimensions and tax evasion", Journal of International Accounting, Auditing and Taxation, Vol. 16, No. 2, pp. 131-147.

32. Wenzel, M. (2005a), "Misperceptions of social norms about tax compliance: From theory to intervention", Journal of Economic Psychology, Vol. 26, No. 6, pp. 862-883.

33. Wenzel, M. (2005b), "Motivation or rationalisation? Causal relations between ethics, norms and tax compliance", Journal of Economic Psychology, Vol. 26, No. 4, pp. 491-508.

34. Williams, C. C., Franić, J., Dzekova, R. (2014), "Explaining the undeclared economy in Bulgaria: an institutional asymmetry perspective", The South East European Journal of Economics and Business, Vol. 9, No. 2, pp. 33-45. 
35. Williams, C. C., Franić, J. (2015), "Tackling the Propensity towards Undeclared Work: Some Policy Lessons from Croatia", The South East European Journal of Economics and Business, Vol. 10, No. 1, pp. 18-31.

36. Williams, C. C., Horodnic, I.A. (2016a), "An institutional theory of the informal economy: some lessons from the United Kingdom", International Journal of Social Economics, Vol. 43, No. 7, pp. 722-738.

37. Williams, C. C., Kayaoglu, A. (2016b), "Tackling the Informal Economy in the European Union: A Social Actor Approach", UTMS Journal of Economics, Vol. 7, No. 2, pp. 133-1 47.

38. Williams, C. C., Franić, J. (2017), "Tackling the illegitimate under-reporting of salaries in Southeast Europe: some lessons from a 2015 survey in Bulgaria, Croatia and FYR Macedonia", Eastern Journal of European Studies, Vol. 8, No. 1, pp. 5-28.

39. Williams, C. C., Bezeredi, S. (2018), "Explaining and tackling the informal economy: a dual informal labour market approach", Employee Relations, Vol. 40, No. 5, pp. 889-902.

40. Windebank, J., Horodnic, I. A. (2017), "Explaining participation in undeclared work in France: lessons for policy evaluation", International Journal of Sociology and Social Policy, Vol. 37, No. 3-4, pp. 203-217.

\section{About the authors}

Predrag Bejaković, PhD is employed at the Institute of Public Finance, Zagreb. He has taken part in a number of projects and has published in scientific and professional journals. He is the author and co-author of a number of books from the areas of the economy, education (particularly VET and adult education), public finance, underground economy and labour economics. His main fields of interests are labour economics, education, social policy, poverty reduction and economic development. Recently he was a team leader for Croatia for the Project Grey related to the underground economy. The author can be contacted at predrag.bejakovic@ijf.hr.

Slavko Bezeredi, univ.spec.oec. is a Researcher at the Institute of Public Finance, Croatia, employed since 2011. Currently, he is a PhD student at Faculty of Economics and Business, University of Zagreb. He has been involved as a member of the Croatian national team in the project EUROMOD (a Europe-wide tax-benefit microsimulation model) since 2013. Recently he was employed as a Marie Curie Research Fellow at the University of Sheffield for a year. His research interests include microsimulations of taxes and social benefits, make work pay policies, labour market and informal economy. The author can be contacted at slavko.bezeredi@ijf.hr. 